\title{
Pengaruh Religiusitas dan Kelompok Referensi Terhadap Keputusan Pembelian
}

\author{
Sarah Fitria ${ }^{1}$, Yessy Artanti ${ }^{2}$ \\ Universitas Negeri Surabaya ${ }^{1}$, Universitas Negeri Surabaya, ${ }^{2}$ \\ sarahfitria04@gmail.com ${ }^{1}$, yessyartanti@unesa.ac.id ${ }^{2}$
}

\begin{abstract}
In recent years the growing fashion trend in Indonesia is a muslim fashion trend. The current trend of muslim clothing in Indonesia such as Rabbani muslim clothing that is in accordance with the teachings of Islamic religion is polite, closed and designed with materials that are not thin or dreamy. This study aims to analyze and discuss the effect of Religiosity and Reference Groups on Purchasing Decisions. This study uses a nonprobability sampling method with judgmental sampling method. The number of samples in this study were 220 respondents were selected were respondents who had bought Muslim clothing Rabbani and aged 17-60 years. The measurement scale uses a likert scale. Data analysis uses multiple linear regression analysis tools. Distribution questionnaires are done offline. The results of this study indicate that Religiosity does not significantly influence Purchasing Decisions. The results also showed that the Reference Group had a significant effect on Purchasing Decisions.
\end{abstract}

Keywords: religiosity, reference groups, and purchasing decisions

\begin{abstract}
Abstrak
Beberapa tahun belakangan ini trend busana yang sedang berkembang di Indonesia adalah trend busana muslim. Trend busana muslim saat ini di Indonesia seperti busana muslim Rabbani yang sesuai ajaran agama islam yang santun, tertutup dan dirancang dengan bahan yang tidak tipis atau menerawang. Penelitian ini bertujuan untuk menganalisis dan membahas pengaruh Religiusitas dan Kelompok referensi terhadap Keputusan Pembelian. Penelitian ini menggunakan metode nonprobability sampling dengan metode judgmental sampling. Jumlah sampel dalam penelitian ini adalah 220 responden dimana yang dipilih adalah responden yang pernah membeli busana muslim Rabbani dan berusia 17-60 tahun. Skala pengukuran menggunakan skala Likert. Analisis data menggunakan alat analisis regresi linear berganda. Penyebaran angket dilakukan secara offline. Hasil penelitian ini menunjukkan bahwa religiusitas tidak berpengaruh signifikan terhadap keputusan pembelian.Hasil penelitian juga menunjukkan bahwa kelopompok referensi berpengaruh signifikan terhadap keputusan pembelian.

Kata Kunci: religiusitas, kelompok referensi, dan keputusan pembelian
\end{abstract}

\section{PENDAHULUAN}

Pada beberapa tahun belakangan ini trend busana yang sedang berkembang di Indonesia adalah trend busana muslim. Busana muslim yang sesuai kaidah ajaran agama Islam merupakan busana yang setidaknya memiliki unsurunsur seperti busana yang santun, tertutup dan dirancang dengan bahan yang tidak tipis atau menerawang. Terdapat pengaruh negatif dan pengaruh positif yang ditimbulkan dari adanya perkembangan trend busana muslim di 
Indonesia saat ini. Salah satu pengaruh positif yaitu perekonomian di Indonesia mengalami kenaikan dari hasil produksi dan penjualan busana muslim. Pengaruh positif lainnya yang ditimbulkan dari adanya trend busana muslimah yang berkembang di Indonesia yaitu semakin banyak muslimah yang menggunakan dan mengikuti perkembangan trend busana muslim sebagai gaya berbusana kesehariannya, contohnya saat bepergian, kuliah atau bekerja pada sebuah instansi tertentu. Semakin banyak wanita muslim yang sadar akan keharusannya menutup aurat seperti yang dianjurkan untuk setiap wanita muslim. Pada saat berbusana wanita muslim juga harus tetap memperhatikan kaidah dari busana muslim tersebut dan tidak hanya sekedar mengikuti trend busana muslim yang sedang berkembang seperti saat ini.

Pengaruh negatif dari mengikuti trend busana muslim yang berkembang di Indonesia seperti saat ini akan menjadi sesuatu yang dipermasalahkan jika trend busana muslim tersebut tidak sesuai dengan kaidah ajaran agama Islam. Seorang perancang busana harus lebih berinovasi untuk membuat hasil karya busana muslim yang modern namun tetap sesuai kaidah ajaran agama Islam. Begitu pula dengan para wanita muslim dalam memilih trend busana muslimahnya harus tetap memperhatikan dan menyesuaikan dengan kaidah ajaran agama Islam. Penggunaan busana muslim yang disesuaikan dengan kaidah ajaran agama Islam akan mewujudkan suatu nilai busana yang baik. Nilai yang dihasilkan dari sebuah busana dapat memperlihatkan sifat atau karakter dari pribadi masing-masing orang.

Pada trend busana muslim yang berkembang di Indonesia seperti saat ini, kehadirannya ditampilkan dengan berbagai macam. Dapat dilihat di kalangan masyarakat, yang paling banyak terlihat adalah seperti jenis busana gamis, blus, kulot, rok dan lain sebagainya. Jenis-jenis busana ini dapat dengan mudah dipadupadankan untuk digunakan dalam kesempatan apapun. Penggunaan busana juga bisa dilihat berdasarkan dari siapa yang akan memakai busana muslimah tersebut. Jika dilihat sejarah busana serba tertutup seperti busana muslim bukanlah busana yang cukup familiar di masyarakat Indonesia sebelumnya. Namun seiring pemahaman atas ajaran islam dan dipeluk oleh mayoritas masyarakat Indonesia busana muslim terus diterima secara luas secara bertahap. Penggunaan busana muslim mulai banyak dikenakan setelah perkembangan hijab diterima. Hal ini bisa dilihat dari banyaknya beberapa foto perempuan Indonesia di tahun 1940an yang banyak mengkombinasikan baju lengan panjang ataupun pendek dengan hijab yang sederhana, yakni hanya berfungsi sebagai penutup kepala atau disampirkan. Seiring kemajuan zaman dan kemudahan masuknya budaya dari luar, perkembangan busana muslim terus berevolusi. Perkembangan tersebut pun mendorong ragamnya busana muslim dari waktu ke waktu di seluruh dunia tak terkecuali Indonesia. Industri busana muslim mulai marak di tanah air sejak tahun 1990an dan booming lima tahun berikutnya. Sejak saat itu makin banyak yang mulai melirik bergaya muslim. Kisaran umurnya pun makin meluas. Pakaian tertutup ini tak hanya dikenakan oleh wanita dewasa namun meluas hingga pada remaja dan anak-anak. 


\section{KAJIAN LITERATUR}

Keputusan pembelian menurut Peter dan Olson (2004) menunjuk bahwa keputusan konsumen berorientasi pada target, dan bahwa konsumen selalu perlu membuat pilihan mengenai berbagai keputusan selama proses penyelesaian masalah. Blackwell, et al (2005) menunjukkan bahwa pengambilan keputusan pembelian dipengaruhi oleh banyak faktor, termasuk promosi toko, suasana, tingkat kebersihan, tingkat layanan, harga, nilai, kenyamanan logistik, dan pengalaman ritel. Ketika konsumen berbelanja mereka tidak hanya memperhatikan faktor eksternal tetapi juga faktor internal. Sebagaimana dijelaskan Sumarwan (2015: 12) mengenai suatu sistem kepercayaan tentang Tuhan yang kemudian sistem tersebut memberikan pedoman tentang aturan hidup bagi pemeluknya di dunia disebut dengan agama.

Komitmen seseorang untuk menjalankan ajaran-ajaran agama yang dianutnya disebut dengan religiusitas. Sebagaimana religiusitas didefinikasikan oleh Johnson B.R, et al (2001) sebagai sejauh mana individu berkomitmen untuk agama dan ajaran yang ada di dalamnya, termasuk komitmen yang berpatokan pada agama terhadap sikap dan perilakunya. Dwiwiyati Astogini, dkk (2011) menyimpulkan religiusitas tidak berpengaruh terhadap keputusan pembelian produk. Sedangkan Asraf (2013) hasil penelitian menyimpulkan religiusitas berpengaruh terhadap keputusan. Anton Bawono (2011) dalam penelitian menyimpulkan religiusitas juga memiliki kontribusi besar dalam mempengaruhi keputusan konsumen.

Kelompok referensi dapat mendorong seseorang membuat keputusan pembelian. Penelitian oleh (Shallu \& Gupta, 2013) menyatakan bahwa, kelompok referensi memiliki pengaruh terhadap keputusan pembelian. Penelitian yang dilakukan oleh Apriyandani, et al (2017), juga mendukung penelitian dengan menyatakan bahwa kelompok referensi memiliki pengaruh signifikan terhadap keputusan pembelian. Berbeda halnya dengan penelitian yang dilakukan oleh Sianturi, et al (2012), dimana hasil penelitiannya mengungkapkan bahwa tidak terdapat pengaruh secara parsial yang signifikan antara kelompok referensi terhadap keputusan pembelian.

Busana muslim di Indonesia sangat beragam. Hal ini dapat terlihat dari banyaknya merek seperti Rabbani, Rabbani merupakan perusahaan busana muslim yang menawarkan produk busana muslim dari anak kecil, dewasa hingga orang tua dan berbagai model modern yang di tawarkan kepada konsumen. Busana muslim Rabbani telah banyak di kritik oleh netizen atas billboard iklan kerudung yang bertuliskan kata-kata mencuri perhatian yakni "Anak jaman now rok makin di atas, prestasi makin di bawah. jangan sampe!" iklan tersebut membuat kontroversi antara Rabbani dan netizen yang bertujuan untuk beriklan tetapi netizen pun mengkritik cara Rabbani itu salah untuk kepentingan promosi penjualan Rabbani.

Berdasarkan latar belakang di atas, maka penulis tertarik meneliti dengan judul "Pengaruh Religiusitas Dan Kelompok Referensi Terhadap Keputusan 
Pembelian Busana Muslim (Studi pada Konsumen Busana Muslim Rabbani di Surabaya)".

\section{Pengaruh Religiusitas dengan Keputusan Pembelian}

Seseorang yang menjadi pemeluk suatu agama akan berpedoman pada ajaran agamanya disaat melakukan seuatu tindakan, salah satuya dalam mengkonsumsi barang dan jasa demi untuk memenuhi kebutuhan hidupnya. Persepsi, motivasi, sikap, dan perilaku konsumen salah satunya akan dipengaruhi oleh ajaran-ajaran agama yang dianutnya (Sumarwan, 2015: 12). Komitmen dalam menjalankan ajaran-ajaran agama yang dianutnya dikenal sebagai religiusitas. Sebagaimana religiusitas didefinikasikan oleh Johnson B.R, et al (2001) sebagai sejauh mana individu berkomitmen untuk agama dan ajaran yang ada di dalamnya, termasuk komitmen yang berpatokan pada agama terhadap sikap dan perilakunya. Dwiwiyati Astogini, dkk (2011) menyimpulkan religiusitas tidak berpengaruh terhadap keputusan pembelian produk. Sedangkan Asraf (2013) hasil penelitian menyimpulkan religiusitas berpengaruh terhadap keputusan. Anton Bawono (2011) dalam penelitian menyimpulkan religiusitas juga memiliki kontribusi besar dalam mempengaruhi keputusan konsumen.

H1: Religiusitas tidak berpemgaruh signifikan terhadap keputusan pembelian

\section{Pengaruh Kelompok Referensi dengan Keputusan Pembelian}

Individu maupun kelompok yang secara nyata memberikan pengaruh perilaku seseorang, Sumarwan (2015: 305). Seluruh kelompok memiliki pengaruh baik secara langung atau secara tidak langsung pada perilaku atau sikap individu tersebut disebut dengan kelompok referensi (Kotler dan Keller, 2009:170). Menurut Mowen (2001; dalam Siamturi, et al, 2012) kelompok referensi merupakan orang yang dapat memberikan pengaruh pada perilaku orang lain. Secara signifikan dapat memberikan standar baik berupa nilai atau norma untuk dapat digunakan sebagai sudut pandang seseorang dalam bertingkah laku maupun berfikir. Kelompok referensi digunakan seseorang sebagai suatu referensi ataupun dasar perbandingan dalam membentuk respons perilaku, afektif, atau kognitif. Sudut pandang, kelompok refrensi mempunyai fungsi sebagai sebuah referensi untuk individu dalam melakukan konsumsi maupun melakukan keputusan pembelian.

Kelompok referensi dapat mendorong seseorang membuat keputusan pembelian. Penelitian oleh Shallu dan Gupta (2013) menyatakan bahwa, kelompok referensi memiliki pengaruh terhadap keputusan pembelian. Penelitian yang dilakukan oleh Apriyandani et al (2017), juga mendukung penelitian dengan menyatakan bahwa kelompok referensi memiliki pengaruh signifikan terhadap keputusan pembelian. Berbeda halnya dengan penelitian yang dilakukan oleh Sianturi et al (2012), dimana hasil penelitiannya mengungkapkan bahwa tidak terdapat pengaruh secara parsial yang signifikan antara kelompok referensi terhadap keputusan pembelian. 
H2: Kelompok referensi berpengaruh signifikan terhadap keputusan pembelian

\section{METODE PENELITIAN}

\section{Jenis Penelitian dan Rancangan Penelitian}

Penelitian ini menggunakan jenis rancangan riset konklusif deskriptif dengan tujuan menguji hipotesis dan menguji hubungan yang spesifik. Rancangan riset dipilih berdasarkan tujuan penelitian ini yaitu menguji pengaruh religiusitas dan kelompok referensi terhadap keputusan pembelian Busana Muslim.

\section{Teknik Pengambilan Sampel}

Pada penelitian ini bertujuan untuk mengukur religiusitas dan kelompok referensi terhadap keputusan pembelian busana muslim. Jumlah sampel yang digunakan sebesar 200 responden. Sedangkan, untuk memperoleh data 200 responden, peneliti menyebarkan 220 responden atau menambahkan $10 \%$ dari ukuran sampel untuk menjaga agar target terpenuhi. Hal tersebut untuk mengantisipasi apabila terdapat angket yang rusak atau tidak memenuhi syarat (Sarwono \& Martadireja, 2008:147-148).

Metode sampling yang digunakan yaitu nonprobability sampling. Teknik pengambilan sampel menggunakan judgemental sampling. Dengan menggunakan teknik judgement, peneliti dapat memilih elemen-elemen yang akan dimasukkan ke dalam sampel, karena elemen-elemen ini sesuai dengan penelitiannya.

\section{Variabel Penelitian dan Definisi Operasional Religiusitas (X1)}

Religiusitas adalah komitmen konsumen menjadikan ajaran agama yang dianut sebagai pedoman untuk membeli busana muslim Rabbani. Indikator religiusitas yang digunakan pada penelitian ini yaitu berdasarkan pada jurnal Alam et al., (2011) dan Muhammad et al., (2017) : (1) Religious value (Nilai religusitas), (2) Religious beliefs (Keyakinan), (3) Ritualistic (Praktik).

\section{Kelompok Referensi (X2)}

Manusia merupakan makhluk sosial sehingga mereka tidak dapat hidup sendiri dan memerlukan kehadiran individu lain. Di dalam hidupnya manusia pasti saling berinteraksi satu sama lain. Hal ini memungkinkan konsumen menjadi bagian dari berbagai kelompok referensi. Adapun indikator yang digunakan untuk mengukur kelompok referensi merujuk pada penelitian yang dilakukan oleh Wibowo et al., (2017), Bearden dan Etzel (2001): (1) Pengetahuan kelompok referensi mengenai produk, (2) Kredibilitas dari kelompok referensi, (3) Pengalaman dari kelompok referensi, (4) Keaktifan dari kelompok referensi, (5) Daya tarik kelompok referensi, (6) Ekspresi nilai. 


\section{Keputusan Pembelian (Y)}

Keputusan pembelian merupakan hal yang menjadi pertimbangan untuk konsumen dalam membeli produk. Berdasarkan penelitian yang digunakan oleh Kotler dan Keller (2013: 178-179) indikator keputusan pembelian yang digunakan adalah (1) Waktu pembelian, (2) Jumlah pembelian, (3) Metode pembayaran.

\section{PEMBAHASAN}

\section{Uji Validitas dan Reliabilitas}

Tabel 1

Hasil Uji Validitas dan Reliabilitas

\begin{tabular}{|c|c|c|c|}
\hline Variabel & $\mathbf{r}^{\text {hitung }}$ & $\begin{array}{l}\mathbf{r} \\
\text { kritis }\end{array}$ & Croncbach's Alpha \\
\hline \multicolumn{4}{|c|}{ Religiusitas (X1) } \\
\hline $\mathrm{X} 1.1 .1$ & 0,507 & \multirow{9}{*}{0,30} & 0,771 \\
\hline $\mathrm{X} 1.1 .2$ & 0,635 & & \\
\hline $\mathrm{X} 1.1 .3$ & 0,653 & & \\
\hline $\mathrm{X} 1.2 .1$ & 0,503 & & \\
\hline $\mathrm{X} 1.2 .2$ & 0,521 & & \\
\hline $\mathrm{X} 1.3 .1$ & 0,694 & & \\
\hline $\mathrm{X} 1.3 .2$ & 0,547 & & \\
\hline $\mathrm{X} 1.3 .3$ & 0,618 & & \\
\hline X1.3.4 & 0,770 & & \\
\hline \multicolumn{4}{|c|}{ Kelompok Referensi (X2) } \\
\hline X2.1.1 & 0,711 & \multirow{12}{*}{0,30} & 0,962 \\
\hline $\mathrm{X} 2.1 .2$ & 0,898 & & \\
\hline $\mathrm{X} 2.2 .1$ & 0,806 & & \\
\hline $\mathrm{X} 2.2 .2$ & 0,807 & & \\
\hline $\mathrm{X} 2.3 .1$ & 0,887 & & \\
\hline $\mathrm{X} 2.3 .2$ & 0,878 & & \\
\hline $\mathrm{X} 2.4 .1$ & 0,851 & & \\
\hline X2.4.2 & 0,869 & & \\
\hline $\mathrm{X} 2.5 .1$ & 0,938 & & \\
\hline $\mathrm{X} 2.5 .2$ & 0,778 & & \\
\hline $\mathrm{X} 2.6 .1$ & 0,801 & & \\
\hline X2.6.1 & 0,895 & & \\
\hline \multicolumn{4}{|c|}{ Keputusan Pembelian (Y) } \\
\hline Y1.1.1 & 0,598 & \multirow{3}{*}{0,30} & 0,654 \\
\hline Y1.1.2 & 0,557 & & \\
\hline Y1.2.1 & 0,703 & & \\
\hline
\end{tabular}




\begin{tabular}{|c|c|}
\hline Y1.2.2 & 0,729 \\
\hline Y1.3.1 & 0,680 \\
\hline Y1.3.2 & 0,419 \\
\hline
\end{tabular}

Sumber: data diolah peneliti

Pada tabel 1 uji validitas menunjukksn bahwa nilai $\mathrm{r}$ hitung atau Corrected Item- Total Correlation $>0,30$ sehingga seluruh item dapat dikatakan valid. Lalu untuk uji reliabilitas dapat diketahui bahwa besarnya nilai Croncbach's Alpha pada ketiga variabel mempunyai besar $>0,60$, sehingga dapat ditarik kesimpulan bahwa pernyataan-pernyataan yang terdapat dalam instrument penelitian variabel religiusitas, kelompok referensi dan keputusan pembelian adalah terbukti reliabel dan layak digunakan.

\section{Teknik Analisis Data}

Teknik analisis data yang digunakan pada penelitian ini yaitu menggunakan analisis regresi liniear berganda untuk mengetahui pengaruh variabel terikat yaitu Keputusan Pembelian (Y) dengan variabel bebas yaitu Religiusitas (X1) dan Kelompok Referensi (X2). Teknik analisis data yang dimaksud adalah model analisis regresi linier berganda dengan menggunakan persamaan menurut (Simamora, 2005:43) :

$$
\mathrm{Y}=\mathrm{a}+\mathrm{b}_{1} \mathrm{X}_{1}+\mathrm{b}_{2} \mathrm{X}_{2}+\ldots .+\mathrm{b}_{\mathrm{n}}+\mathrm{X}_{\mathrm{n}}+\mathrm{e}
$$

Dengan dasar persamaa diatas, maka persamaan untuk penelitian ini yakni:

$$
\mathrm{Y}=\mathrm{a}+\mathrm{b}_{1} \mathrm{X}_{1}+\mathrm{b}_{2} \mathrm{X}_{2}+\mathrm{e}
$$

\section{Hasil penelitian menggunakan uji regresi linier berganda}

Tabel 2 Hasil Analisis Regresi Linier Berganda Coefficients $^{\mathrm{a}}$

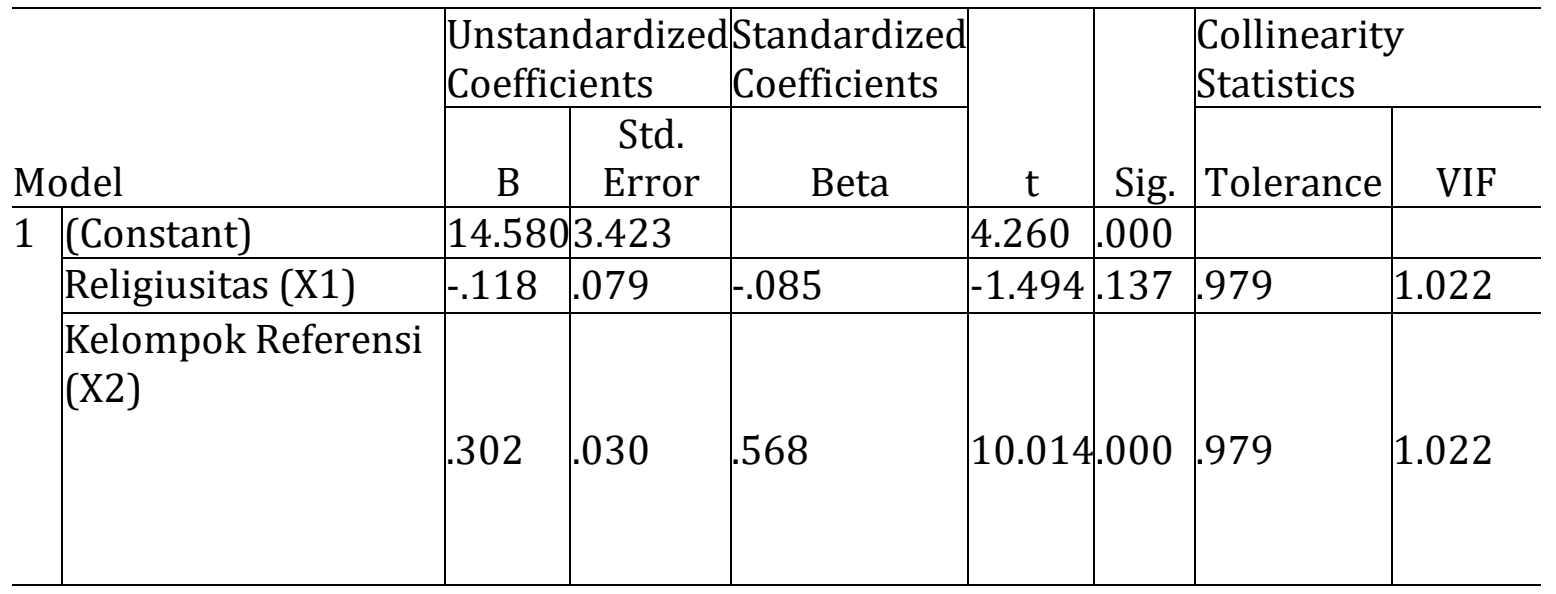

a. Dependent Variable: Keputusan Pembelian (Y)

Sumber: Output SPSS 23 
Pada tabel 2 dapat diperoleh model persamaan regresi linier berganda sebagai berikut:

$\mathrm{Y}=14.580+-0,118 \mathrm{X} 1+0,302 \mathrm{X} 2$

Keterangan:

$\mathrm{Y} \quad=$ Keputusan Pembelian

$\mathrm{X} 1=$ Religiusitas

$\mathrm{X} 2=$ Kelompok Referensi

Pada model regresi linier berganda, maka dapat diperoleh hasil yaitu, Nilai konstanta (a) adalah 14.580. Artinya, bahwa jika religusitas, kelompok referensi sama dengan nol (0) maka besarnya keputusan pembelian adalah 14.580. maka tanda positif konstanta yaitu meskipun tidak ada pengaruh religiusitas, kelompok referensi maka keputusan pembelian tetap terjadi dengan nilai sebesar yaitu 14.580. Nilai koefisien religusitas (X1) adalah sebesar -0,118. Artinya, religiusitas (X1) rendah namun keputusan pembelian tinggi, maka responden melakukan belanja atau membeli busana muslim keputusan pembelian tingggi walaupun religiusitas rendah. Rendahnya religiusitas sebesar -0.118 koefisien negatif. Koefisien Regresi untuk Variabel Kelompok referensi (X2) nilai koefisien (X2) sebesar 0,302. Artinya, jika kelompok referensi positif tentang membeli busana muslim Rabbani yang diterima responden itu semakin banyak, maka keputusan pembelian (Y) busana muslim Rabbani meningkat. Kenaikan kelompok referensi positif sebesar satuan akan meningkatkan keputusan pembelian (Y) responden sebesar 0,302 koefisien bernilai positif. Hal ini melambangkan adanya hubungan searah kelompok referensi dengan keputusan pembelian.

Uji kelayakan model pengujian tentang pengaruh religiusitas, kelompok referensi terhadap keputusa pembelian mebghasilkan nilai $\mathrm{R}$ (korelasi) dan R2 (Adjusted R Square), dapat diketahui bahwa besarnya kontribusi variabel bebas religiusitas (X1), kelompok referensi (X2) terhadap variabel terikat keputusan pembelian (Y). Nilai adjusted R square sebesar 0,310=31,0\%. Berdasarkan nilai tersebut menunjukkan bahwa religiusitas (X1), kelompok referensi (X2) mempengaruhi keputusan pembelian busana muslim sebesar 0,310 atau 31,0\%. Sedangkan sisanya 79,0\% dipengaruhu oleh variabel diluar variabel yang digunakan pada penelitian ini.

Pada penelitian ini uji t digunakan untuk menguji pengaruh variabel-variabel bebas (X) terhadap variabel terikat (Y) secara satu-persatu atau secara individual pada responden, yakni dengan ketentuan jika nilai signifikansi < $0,05(\alpha=5 \%)$, maka variabel bebas secara parsial berpengaruh signifikan terhadap variabel terikat.

Hasil dari penelitian ini menjelaskan bahwa dalam melakukan keputusan pembelian busana muslim Rabbani responden tidak harus memiliki tingkat religiusitas yang tinggi dalam pengambilan keputusan pembelian terhadap produk rabbani, hal tersebut juga dapat dikarenakan oleh faktor-faktor yang lain seperti trend fashion yang pada akhir-akhir ini sedang berkembang trend fashion muslim dunia. perkembangan fashion dunia, yang mana hal ini 
diikuti oleh Rabbani dalam perkembangan produk busana muslimnya. hal ini terlihat dari produk produk rabbani yang selalu muncul dengan konsep yang baru setiap tahunnya, dan Hasil penelitian ini membuktikan bahwa kelompok referensi dalam penelitian ini yaitu teman dekat yang sudah pernah membeli busana muslim Rabbani memiliki peran penting dalam mempengaruhi calon pembeli untuk membeli busana muslim Rabbani. Hal tersebut dikarenakan teman yang sudah pernah membeli tersebut dianggap memiliki informasi lebih tentang busana muslim Rabbani. Informasi tersebut seperti harga, kualitas bahan dan tentang yang lain. Selain informasi-informasi yang sudah diberikan, calon pembeli akan memiliki ketertarikan untuk mengikuti pengaruh teman yang sudah pernah membeli busana muslim Rabbani. Hal ini menunjukkan bahwa kelompok referensi mendorong calon pembeli untuk melakukan keputusan pembelian busana muslim.

\section{SIMPULAN}

Penelitian ini membuktikan bahwa religiusitas tidak berpengaruh signifikan terhadap keputusan pembelian busana muslim Rabbani. Penelitian ini juga membuktikan bahwa kelompok referensi berepengaruh signifikan terhadap keputusan pembelian busana muslim Rabbani. Hal tersebut daoat dilihat dari setiap variabel religiusitas menjelaskan bahwa dalam melakukan keputusan pembelian busana muslim Rabbani responden tidak harus memiliki tingkat religiusitas yang tinggi dalam pengambilan keputusan pembelian terhadap produk rabbani, hal tersebut juga dapat dikarenakan oleh faktor-faktor yang lain seperti trend fashion yang pada akhir-akhir ini sedang berkembang trend fashion muslim dunia. perkembangan fashion dunia, yang mana hal ini diikuti oleh Rabbani dalam perkembangan produk busana muslimnya. hal ini terlihat dari produk produk rabbani yang selalu muncul dengan konsep yang baru setiap tahunnya, dan variabel kelompok referensi teman dekat yang sudah pernah membeli busana muslim Rabbani memiliki peran penting dalam mempengaruhi calon pembeli untuk membeli busana muslim Rabbani. Hal tersebut dikarenakan teman yang sudah pernah membeli tersebut dianggap memiliki informasi lebih tentang busana muslim Rabbani. Informasi tersebut seperti harga, kualitas bahan dan tentang yang lain. Selain informasi-informasi yang sudah diberikan, calon pembeli akan memiliki ketertarikan untuk mengikuti pengaruh teman yang sudah pernah membeli busana muslim Rabbani. Hal ini menunjukkan bahwa kelompok referensi mendorong calon pembeli untuk melakukan keputusan pembelian busana muslim.

\section{DAFTAR PUSTAKA}

Ahmad, A. N., Rahman, A. A., \& Rahman, S. A. (2015). Assessing Knowledge and Religiosity on Consumer Behavior towards Halal Food and Cosmetic Products. International Journal of Social Science and Humanity, 5(1), 1014. https://doi.org/10.7763/ijssh.2015.v5.413.

Alam, S. S., Mohd, R., \& Hisham, B. (2011). Is religiosity an important 
determinant on Muslim consumer behaviour in Malaysia? Journal of Islamic Marketing, 2(1), 83-96. https://doi.org/10.1108/ 1759083111 1115268.

As, M., Othman, J., Ikhwan Setiawan, A., Imronudin, Wulandari, F., \& Kostrad Diharto, A. (2018). EDITORIAL TEAM RELEVANCE Journal of Management and EDITORIAL TEAM Editorial in Chief Editorial Boards Managing Editor. In RELEVANCE Journal of Management and Business (Vol. 1).

Astogini, D., Wahyudin, \& Wulandari, S. Z. (2011). Aspek Religiusitas dalam Keputusan Pembelian Produk Halal. Jeba, 13(1), 1-8.

Bawono, A. (2017). Kontribusi Religiusitas dalam Perilaku Pengambilan Keputusan Konsumsi. MUQTASID Jurnal Ekonomi Dan Perbankan Syariah, 2(1), 115. https://doi.org/10.18326/muqtasid.v2i1.115-134

Bearden 1982_Reference Groups and Brands.Pdf. (2001).

Fakultas, A., Universitas, E., \& Universitas, F. E. (2012). Vol 1 No.2 April - Juni 2012. 1(2), 127-136.

Ghozali, I. (2016). Aplikasi Analisis Multivariete Dengan Program IBM SPSS 23. Semarang: Badan Penerbit Universitas Diponegoro.

Lin, L.-Y., \& Shih, H.-Y. (2012). The Relationship of University Student's Lifestyle, Money Attitude, Personal Value and their Purchase Decision. International Journal of Research in Management, 1(2001), 19-37. Retrieved from The Relationshio of university student\%22s lifestyle, money attitude, personal value and their purchase decision

Muhamad, N., Leong, V. S., \& Md Isa, N. (2017). Does the country of origin of a halal logo matter? The case of packaged food purchases. Review of International Business and Strategy, 27(4), 484-500. https://doi.org/10.1108/RIBS-06-2017-0049

Nasution, M. D. T. P., \& Rossanty, Y. (2016). Hubungan antara Religiusitas dan Pengambilan Keputusan Membeli Panganan Halal dimoderasi oleh Persepsi Konsumen atas risiko. Jurnal Ilmiah Research Sains, 2(2), 7-13.

Novita, D., Achmad, S., Dh, F., Deasyana, L., \& Devita, R. (2018). PENGARUH TREND FASHION TERHADAP KEPUTUSAN PEMBELIAN (Survei pada Konsumen Wanita Butik Ria Miranda Cabang Malang). In Jurnal Administrasi Bisnis (JAB)/Vol (Vol. 60). Retrieved from https://kbbi.web.id/butik

Pembelian, K., Jambi, B., \& Kota, D. I. (2015). Abstrak. 17.

Rahman, M., Albaity, M., \& Maruf, B. (2017). The Role of Religiosity on the Relationship Between Materialism and Fashion Clothing Consumption Among Malaysian Generation Y Consumers. Social Indicators Research, 132(2), 757-783. https://doi.org/10.1007/s11205-016-1310-9

Riyadi2, A. F. W. dan E. S. H. (2017). ( Studi Pada Konsumen Taiwan Tea House Semarang ). 97-113.

Rahman, M., Albaity, M., \& Maruf, B. (2017). The Role of Religiosity on the Relationship

Shallu, \& Gupta, S. (2013). “ Impact of Promotional Activities on Consumer 
Pengaruh Religiusitas dan Kelompok Referensi Terhadap Keputusan

Pembelian

Buying Behavior : A Study of Cosmetic Industry." International Journal of Commerce, Business and Management (IJCBM), 2(6), 379-385. Retrieved from

http://www.iracst.org/ijcbm/papers/vol2no62013/11vol2no6.pdf

Simamora, B. (2005). Analisis Multivariat Pemasaran. Jakarta: Gramedia Pustaka Utama.

Sumarwan. (2015). perilaku konsumen teori dan penerapannya dalam pemasaran.

Yulianto, E. (2015). Pengaruh Gaya Hidup dan Kelompok Referensi Terhadap Keputusan Pembelian ( Survei Mahasiswa S1 Fakultas Ilmu Administrasi Angkatan 2014 dan 2015 Universitas Brawijaya Malang yang Membeli dan Menggunakan Smartphone iPhone ). Universitas Brawijaya Malang, 50(2), 180-189. 
Halaman ini sengaja di kosongkan 